\title{
Changes in political relevance of The League of Polish Families in result of parliamentary, municipal and European elections
}

The League of Polish Families, political relevance, elections

KEY WORDS:

The League of Polish Families, political relevance, elections

\section{Introduction}

The League of Polish Families was founded in 2001 as the continuation of the National Party (SN) and the National-Democratic Party (SND)- groups that referred to the inter-war ideology of the National Democracy Party. The activists from SN and SND became its leaders: Marek Kotlinowski became the head of the Central Board and Roman Giertych became the head of the Committee, whereas Zygmunt Wrzodak, leader of 'Solidarność' in Ursus Mechanical Plant in Warsaw, the Head of Political Council. LPR referred to national-democratic ideas: compliance of Polish politics with the interest of the nation, maintaining independence and sovereignty of the state, economic and social development, as well as national solidarity ${ }^{1}$.

The article is an analysis of the evolution of LPR's relevance on the Polish political stage. The term shall be understood as the ability of a political party to influence, in the direct and repetitive manner, the formulation and implementation of the policy of state as the co-governing entity and effective opposition ${ }^{2}$. The aim of the article is to prove the hypothesis that LPR had substantial potential

1 C. Maj, E. Maj, Narodowe ugrupowania polityczne w Polsce: 1989-2001, Lublin 2007, p. $257-265$.

2 A. Antoszewski, Relewancja partii politycznej, [in:] A. Antoszewski, R. Herbut (eds.), Encyklopedia politologii, vol. 3: Partie i systemy partyjne, Kraków 1999, p. 212-213. 
to become an influential national party in Poland, but did not make use of it and from a co-governing group it eventually became a non-parliamentary party with diminishing political influence. The following questions were helpful for that purpose:

1) What was the organizational foundation of LPR?

2) What position did the League have on the Polish political stage?

3) What was the reason for political success and eventual failure of the party?

\section{The initial stage of political activity}

The ambition of LPR was the strive to unite the political parties referring, first and foremost, to national, but also conservative values, which was supposed to be an alternative to the elites ruling Poland that were considered liberal, secular and cosmopolitan. Such a coalition was supposed to gain power in the country and lead to calling to account the leaders of the Peoples' Republic of Poland and the Third Republic of Poland accused of selling out public assets and leading to economic downfall of the state ${ }^{3}$. The first month of the League's existence brought their leaders success: different parties sharing the values akin to the neo-national democracy and lead by recognizable figures from the right side of the political spectrum started to unite around it. Among them were the Polish Agreement (Porozumienie Polskie) of Jan Łopuszański, the National-Catholic Movement of Antoni Macierewicz, the Polish Alliance of Gabriel Janowski and the Movement for Reconstruction of Poland of Jan Olszewski ${ }^{4}$.

The objective of LPR was to gain strong position in the parliament and to become a party in opposition to the politicians from post-communist groups and opposition of the People's Republic period who concluded the Round Table Agreement in April $1989^{5}$. The time remaining to the parliamentary elections in September 2001 was devoted to getting parliamentary mandates. The election programs focused on several main issues; these included: defence of political and economic sovereignty, creating effective administration, economic growth, alleviating the social life standard and creating law based on catholic and national values ${ }^{6}$.

3 C. Maj, E. Maj, Narodowe ugrupowania..., p. 258-260.

4 M. Wójcik, „Ojcowizna” razem z Liga, «Nasz Dziennik» (next: ND), 18 VII 2001, № 166, p. 3.

5 Karta Praw Polaków, «Myśl Polska na Wybory» (next: MPW), 9 IX 2001, № 6, p. II.

6 Ibidem; Polsce - Niepodległość. Polakom - Praca, Chleb, Mieszkanie. Odezwa do Narodu Polskiego, «MPW», 19 VIII 2001, № 3, p. I. 
In the elections of 23.11.2001 the League achieved a success - 1025148 people voted for it, which comprised $7,78 \%$ of all validly cast votes. It exceeded the electoral threshold and the party entered the parliament, introducing 38 candidates and becoming the first national party in the Polish parliament since 1930. Most votes casted for LPR were casted in electoral districts no 23 (Rzeszów) - 67123 and no 19 (Warsaw I) - 52 331, and by percentage in districts no $23-15,78 \%$ and no 15 (Tarnów) - 13,02\%. The lowest number of votes were casted in districts no 40 (Koszalin) - 9161 and 32 (Sosnowiec) - 11111 ; the percentage results were also the lowest there: $3,97 \%$ (no 32 ) and 4,45\% (40) respectively. The most mandates were gained in districts no $23-3$, as well as 6 (Lublin), 13 (Kraków), 19 and 24 (Białystok) -2 in each one (elections in 2001)7. Good election result was the effect of consolidation of national and catholic forces within one group, which limited dissipating votes of the electorate.

LPR was within the parliament the sixth, and the smallest parliamentary group consisting of $36 \mathrm{MPs}$, as two candidates of ROP (the Movement for Reconstruction of Poland) did not affiliate with the League. Kotlinowski became the leader and the presidium included Giertych, Janowski, Łopuszański, Macierewicz, Wrzodak and Anna Sobecka ${ }^{8}$. LPR became an opposition party to the government of Leszek Miller, formed by the coalition of Democratic Left Alliance, Labour United, and Polish People's Party. A small size of the group resulted in small influences on the Parliament institutions. The members did not manage to get a post of vicemarshal, and while allocating posts within the commissions, LPR received the head post in only one of them- the Commission on Communications with Poles Living Abroad, which was succeeded by Giertych, who kept it until the end of the term. Four MPs became deputy-heads of different commissions 9 .

During the 4th term the number of members varied in LPR to eventually amount 19 in September 2005. At the end of 2002 ten MPs left RKN, PP and PdP and in April 2004 eight MPs formed a parliamentary club 'Dom Ojczysty' (the Homeland). The reasons that were provided included, among others, reluctance to the authoritarian way of exercising their power by R. Giertych and Kotlinowski, as well as program differences, including the attitude towards the war in Afghanistan or elections to the European Parliament. LPR was joined by 3 MPs from PSL (Polish People's Party) and one from Self-Defence and Law and Justice ${ }^{10}$.

7 Wybory parlamentarne 2001, http://wybory2001.pkw.gov.pl, (access: 1.10.2018).

8 C. Maj, E. Maj, Narodowe ugrupowania ..., p. 251.

9 Archiwum Danych o Posłach 2001-2005, http://orka.sejm.gov.pl/ArchAll2.nsf/Glowny4kad (access: 1.10.2018).

10 Ibidem; M.D.Z., Eurosceptyczni nomadowie, «Rzeczpospolita» (next: Rz), 10 XII 2002, № 287, p. 4; P.Ś., Ewakuacja z LPR, «Rz» 15 IV 2004, № 89, p. 4. 


\section{Political success}

At the turn of 2002 and 2003 LPR included about 12000 members $^{11}$ and it attempted to reinforce its position in the Polish political system. Their leaders began to strive to gain influence in particular regions and began preparations to municipal elections. The election program declared implementation of a municipal reform that relied on making regional and local authorities serve interests of citizens. The main tasks that municipal authorities had to do at the level of boroughs, counties and voivodeships, such as landscape planning, investments in infrastructure, economy, healthcare, social services and education, simulating the work market and protecting public security were presented ${ }^{12}$.

In the elections of 27.10.2002 the League achieved greater success than a year before, as the level of local voivodeship parliaments 1603081 votes were casted for it on the nationwide scale, which comprised $12,28 \%$ of all the validly casted votes. The League received 92 mandates, which positioned it in the fourth place nationwide. Most votes were casted for LPR in the Masovian Voivodeship (215 103) and Lesser-Poland (175 025), and by percentage - in the Subcarpathian Voivodeship $(22,86 \%)$ and the Lublin Voivodeship (18,36\%). The fewest votes were casted in the Lubusz Voivodeship (36 403) and the Holy Cross Voivodeship (45 052), and by percentage - in the Holy Cross Voivodeship (10\%) and the Pomeranian (10,36\%). The League got mandates in voivodeship parliaments of all voivodeships, the most of which was in Lesser Poland and Sub-Carpathia - 9 in each (in the second province it got the first place) ${ }^{13}$.

Electoral successes did not always translate into gaining influence on regional authorities. In the Sub-Carpathian Voivodeship LPR did not form a majority coalition due to the lack of agreement with the Civic Platform (PO) and the Law and Justice party (PiS). In result the political power was seized by the coalition of SLD - PSL - Self-defence ${ }^{14}$. The League, however, managed to enter the executive boards of Lubusz, Lesser Poland and Masovian voivodeships. Stanisław Gogacz became the first vice-marshal, whereas Jan Chróścikowski became the executive board member; they, however, held their posts for a month (December 2002-January 2003). In May 2005 LPR regained power and its representative, Tomasz Miszczuk, became the board member, holding his post until the end of the term. In the Lesser-Poland Voivodeship Jan Bereza and Wiesław

\footnotetext{
11 M.D. Zdort, Recepta na rozłamy, «Rz» 8 V 2002, № 106, p. 9; S. Chruszcz, Nasze dziesięć tygodni, «Racja Polska» (next: RP), 30 III 2003, № 5, p. 25.

12 Ramowy program Ligi Polskich Rodzin dla wyborów samorządowych, «Sejm Library» (next: SL), № I.074/01.

13 Wybory samorzadowe 2002, http://wybory2002.pkw.gov.pl, (access: 1.10.2018).

14 MAT, Bastion w opozycji, «Rz» 19 XI 2002, № 269, p. 3.
} 
Zimowski were the executive board members for the whole term (November 2002-November 2006). In the Mazovian Voivodeship LPR was also included in authority institutions for the whole term. Vice-marshals were: Wojciech Wierzejski (November 2002-July 2004), Bogusław Kowalski (October 2003-October 2005) and Waldemar Roszkiewicz (October 2005-November 2006), and the executive board members were: Kowalski (November 2002-October 2003), Roszkiewicz (June 2002-October 2005) and Jan Engelgard (October 2005-November 2006). In three voivodeships LPR entered the executive boards in a later period. In the Lower-Silesia Voivodeship the members of authority institutions were ViceMarshal Artut Paprota and Rafał Borutko (August 2004-November 2006); in the Łódź Voivodeship vicemarshal Marek Ratuszniak (March-November 2004), as well as Paweł Chruszcz (March-June 2004) and Jadwiga Beda (June-November 2004), whereas in the Greater Poland Voivodeship vice-marshal Przemysław Piasta (October 2005-November 2006) ${ }^{15}$.

In years 2003-2004 LPR was dealing with the issues of the European Union: preparations to the accession referendum and elections to the European Parliament. In the referendum campaign the League opposed accession, presenting the threats that presence within the EU structures would bring to Poland: loss of sovereignty as well as social and economic downfall of the state ${ }^{16}$. The referendum of $7^{\text {th }}$ and $8^{\text {th }}$ of May 2003 was a success of integration supporters, but almost 4 million people $(22,55 \%)$ voted against the accession, which was considered by LPR as a success ${ }^{17}$. The party board decided to take part in the elections to the EU parliament, claiming that participation in the electoral campaign would be a possibility to show the League's program in media ${ }^{18}$. While preparing to the elections LPR presented the goals that were set: maintaining sovereignty of Poland against subordination to the EU authorities, attempts for appropriate allocation of EU funds, enabling development of the Polish state, creating law on the basis of Christian values, as well as protecting Polish economy against expansion on the side of the developed countries ${ }^{19}$.

The elections of 13.06.2004 brought another success to the League of Polish Families. 969689 voters voted for it, which comprised 15,92\% of validly cast votes and translated into 10 mandates. The League had second place in the elections.

15 Information, which were gained from marshal offices.

16 Program Polski nowoczesnej, «RP» 13-20 IV 2003, № 7-8, p. 9; Wolna Polska poza Unia, «RP» 27 IV-4 V 2003, № 9-10, p. 4.

17 Referendum $2003 \mathrm{roku}$, http://referendum2003.pkw.gov.pl/sww/kraj/indexA.html, (access: 1.10.2018).

18 Stanowisko II Kongresu LPR w sprawie sytuacji politycznej Polski po zaakceptowaniu w referendum przez Naród wejścia Polski do UE, «RP» September 2003, № 28, p. 8.

19 Naszym celem jest obrona tożsamości i suwerenności Polski, «Nowa Myśl Polska» 25 IV 2004, № 17, p. 3. 
Most people voted for it in the electoral districts no 10 (Kraków) - 150091 and no 11 (Katowice) - 92 326, and by percentage in districts no 9 (Rzeszów) - 24\% and no 8 (Lublin) $-23,59 \%$. The lowest support for the League was in district no 2 (Budgoszcz) - 46221 and no 1 (Gdańsk) - 54 608, and by percentage in electoral district no 4 (Warsaw) - 10,53\% and 13 (Gorzów Wielkopolski) - 12,08\%. LPR did not receive mandates in three districts and in other ones it got one mandate in each district ${ }^{20}$. High position of LPR was the effect of low turnover and relatively effective propaganda, threatening the citizens with the dangers on the part of the European Union and presenting a positive alternative to accession.

Electoral success caused that the leaders of the League were announcing victory in the next parliamentary elections ${ }^{21}$. The next electoral campaign in September 2005 was prepared with that thought in mind. Attention was paid to the changes that LPR was about to bring after winning the elections. The aim of the League was to create the Fourth Republic of Poland, a system that would guarantee independence of Poland in internal and international politics and ensure economic and social growth of the state and its citizens. There was a strive to prevent transferring sovereign competences of the Polish state to other entities, to make the institutions of authority and administration more effective, to create the foundations of economic self-sustainability, as well as to adopt financial and tax policy enabling emergence and development of Polish enterprises and alleviating the life standard of people 22 .

The elections of 25.11.2005 indicated, however, diminishing influence of LPR which received 940762 votes $(7,97 \%)$, so over 80 thousand votes fewer than four years ago. This translated into 34 parliamentary posts. The most votes for the League were casted in districts no 23 (Rzeszów) - 52776 and no 6 (Lublin) - 49 044; by percentage - in district 22 (Krosno) - 13,63\% and no $23-13,09 \%$. The League received the fewest votes in district 40 (Koszalin) - 8083, as well as no 34 (Elblagg) - 9289 , and by percentage in districts no $40-4,61 \%$ and 31 (Katowice) - 4,97\%. In 11 districts LPR did not get a single mandate. In 5 districts the League gained 2 mandates: no 6, no 7 (Chełm), no 22, no 23 and no 24 (Białystok) ${ }^{23}$. The result that was worse than expected was due to conflicts within the party and club structures of the fourth term. In the Subcarpathian Voivodeship there was a struggle between the supporters of Wrzodak and R. Giertych ${ }^{24}$. In the Warmian-Masurian Voivodeship the central authorities, without an agreement with the provincial board, compiled their own lists of candidates to the parliament,

20 Wybory do Parlamentu Europejskiego 2004, http://pe2004.pkw.gov.pl, (access: 1.10.2018).

21 R. Giertych, Chcemy wygrać!, «RP» January 2005, № 1, p. 5.

22 Konstytucja IV RP, Warszawa 2005; km, Znamy programy, «RP» August 2005, № 5, p. 31.

23 Wybory parlamentarne 2005, http://wybory2005.pkw.gov.pl, 1.10.2018.

24 J. Matusz, Brudna wojna o bastion, «Rz» 22 II 2005, № 44, p. 4. 
which comprised of the people from outside the voivodeship. This caused the voivodeship board to hand over resignation and dissolve the voivodeship structures of $\mathrm{LPR}^{25}$. The party leaders were accused of promoting Giertych and his followers from the All-Polish Youth, and disregarding the distinguished national activists ${ }^{26}$. This caused the loss of trust to the party on a part of the electorate. In result of the conflict the party authorities purged the opposition members from the party, including MP Wrzodak or MEP Bogdan Wrodak, the Deputy Head of LPR. One MP and three MEPs were also purged from the party ${ }^{27}$.

In the parliament LPR formed a club including $32 \mathrm{MPs}$, becoming, thus, the fifth parliamentary club in size. Giertych was its leader and in the presidium there were, among others, Sobecka, Kotlinowski, Bogusław Kowalski and Janusz Dobrosz ${ }^{28}$. Although LPR included few MPs, the support for the minority government of Kazimierz Marcinkiewicz from PiS caused that its position in the parliament of the $5^{\text {th }}$ term was stronger than four years before. Kotlinowski became Vice-Marshal of the parliament, and four MPs received posts of committee leaders: Dobrosz (Commission on Communications with Poles Living Abroad), Giertych (Commission of Secret Service), Kowalski (Commission of Infrastructure) and Sobecka (Commission on Family and Women Rights). The League also received posts of commission deputies of 8 commissions ${ }^{29}$.

During the fifth term of the parliament the League decreased in number and at the moment of its conclusion in October 2007 it included 29 MPs. It was also caused by another conflict in the structures between central structures, led by Giertych who had been elected a leader in October 2007, and the Deputy Head Kowalski and Sobecka. The followers of Kowalski wanted the League to establish collaboration with PiS and enter the government as a coalition member. For that purpose they initiated talks with the representatives of the ruling party. The followers of Giertych preferred to stay in opposition and critically assess the activity of the ruling politicians so as to co-opt a part of PiS electorate. The conflict resulted in five MPs leaving the party in April 2005; they founded the National Parliamentary Group and established cooperation with PiS (two of them returned to the League after a month) ${ }^{30}$.

25 i.t., Sekta Giertycha, imperium strachu, «Rz» 29 VIII 2005, № 201, p. 4.

26 P. Śmiłowicz, Wrzodak w Domu Ojczystym, «Rz» 8 VIII 2005, № 184, p. 5.

27 ola, Spychaja Wrzodaka na boczny tor, «Rz» 17 X 2005, № 243, p. 4.

28 Nowy Sejm, nowy klub, nowy przewodniczacy, http://www.lpr.pl/pl/2005/09/29/nowy-sejmnowy-klub-nowy-przewodniczacy, 1.10.2018.

29 Archiwum Danych o Posłach 2005-2007, http://orka.sejm.gov.pl/ArchAll2.nsf/ Glowny5kad, (access: 1.10.2018).

30 W. Wybranowski, Czy LPR się kurczy?, «ND» 30 III 2006, № 76, p. 5; M. Goss, Pęknięcie w politycznym tyglu, «ND» 19 IV 2006, № 92, p. 3; M. Wójcik, Tercet zamiast kwartetu, «ND» 28 IV 2006, № 180, p. 3. 
The conflict in LPR forced the party leaders to initiate talks. It turned out that many local leaders supported accession of the League to the government and were not satisfied with Giertych policy, who opposed that. Such situation occurred, among others, in Kuyavian-Pomeranian, Lubusz and Greater Poland voivodeships ${ }^{31}$. Eventually, on the $5^{\text {th }}$ of May 2006 a coalition including PiS, SelfDefence and LPR was formed and the League received two ministries: Giertych became Deputy Prime Minister and the Minister of National Education and Rafał Wiechecki the Minister of Marine Economy ${ }^{32}$. The party also received the posts of deputy ministers in the ministries of economy, regional development and construction, marine economy, as well as in the European Integration Committee and Prime Minister's Office. The League remained in the ruling coalition for 15 months, until 13.08.2007, when Prime Minister Jarosław Kaczyński concluded the coalition and restored the minority government ${ }^{33}$. It was the first time since the government of Tomasz Arciszewski that a national party had representatives in the government of the Republic of Poland.

\section{Political downfall}

The League was preparing for the next municipal elections in the atmosphere of inner-party conflicts. Repressions towards local leaders supporting Kowalski and Sobecka led to the decrease of support for the LPR board on the side of provincial structures, and leaving the party by them. Since August 2006 the councillors abolished LPR clubs in the municipal governments of KuyavianPomeranian, Silesian, West Pomeranian, Opole, Podlaskie, Mazovian and Greater Poland voivodeships, expressing their support for the MPs of the National Parliamentary Club ${ }^{34}$. Despite those difficulties the leaders of LPR attempted to appeal to the pro-family program so as to unite the electorate. Among the goals the following were mentioned: ensuring safety in public places, granting property rights to the owners of council houses, mobilization of municipal governments for implementing pro-development policy, development of local economy, appropriate social and educational policy and effective use of the EU funds ${ }^{35}$.

The elections of 12.11.2006 resulted in the defeat of LPR. At the level of municipal governments the party received 568935 votes, which was over one

\footnotetext{
31 W. Wybranowski, Chca sojuszu, więc rozmawiaja, «ND» 6-7 V 2005, № 105, p. 4.

32 M. Wójcik, Rząd ma większość w parlamencie, «ND» 6-7 V 2006, № 105, p. 1.

33 M. Stawarska, Teraz tylko PiS, «ND» 14-15 VIII 2007, № 189, p. 1.

34 W. Wybranowski, Już nie z Liga, «ND» 16 VIII 2006, № 190, p. 4; idem, Pękaja struktury Ligi, «ND» 2-3 IX 2006, № 205, p. 3.

35 Z troska w przyszłość. W odpowiedzialności za Państwo, «SL» № I.074/02.
} 
million fewer than four years before and amounted 3,95\% of all validly casted votes. Most people voted for the League in Mazovian (104 458) and Lesser Poland (63 662) viovodeships, and by percentage - in Lubusz (6,52\%) and Lesser Poland (6,18\%). The lowest support for LPR was in Opole (9536) and Lubusz (13 962), and by percentage - in Opole (3,36\%) and Silesia (3,47\%). LPR received 11 mandates, which positioned it at the sixth place nationwide. Four mandates were received in Lesser Poland and in Mazovian voivodeships, 2 in Sub-Carpathia and 1 in Lubusz ${ }^{36}$. For several months it was a coalition member in the executive boards of 2 voivodeships. In November 2006 Waldemar Roszkiewicz (Mazovian Voivodeship) and Wojciech Bosak (Lesser Poland) were nominated Vice-Marshalls. Roszkiewicz soon moved to PSL, whereas Bosak was recalled from his post in March 2007. Thus, LPR stopped playing a role in municipal politics ${ }^{37}$.

In September 2007 the parliament shortened its term, forcing the League to prepare to new electoral campaign. At the moment of the term's end the position of LPR in the parliament was strong: it had a vice-marshal, namely Dobrosz who had held this post since November 2006, 3 deputy heads of commissions: Janusz Kołodziej (Commission of Infrastructure), Leszek Murzyn (Commission on Parliamentary Ethics) and Stanisłąw Zadora (Commission on Communications with Poles Living Abroad) and 6 deputy heads ${ }^{38}$. The surveys, however, did not hold out the prospects of getting parliamentary mandates. Therefore the party tried to bind with other parties, so as the increase the electorate: firstly with SelfDefence, creating a structure called the League and Self-Defence ${ }^{39}$, and then with Real Politics Union and the Right Wing of the Republic, creating the coalition called the League of the Right Wing of Poland ${ }^{40}$. Among the main goals the following were being mentioned: reinforcement of Polish sovereignty by rejection of the Treaty of Lisbon and objection towards changing Polish zloty for euro, pro-development tax policy and continuation of the pro-family policy ${ }^{41}$.

The elections of 21.10.2007 ended in a defeat of LPR, for which 209171 people casted their votes, which was over 700 thousand fewer than 2 years before. This comprised $1,3 \%$ of all validly casted votes, which was insufficient to enter the parliament. Most people voted for LPR in electoral districts no 19 (Warsaw I) - 14264 and no 6 (Lublin) - 9602, by percentage in districts no 7 (Chełm) -

36 Wybory samorzadowe 2006, http://wybory2006.pkw.gov.pl/kbw/geoKrajd41d.html?, (access: 1.10.2018).

37 Information, which were gained from marshal offices.

38 Archiwum Danych o Posłach 2005-2007...

39 B. Waszkielewicz, Akrobacje polityczne Leppera i Giertycha, «Rz»18-19 VIII 2007, № 192 , p. 3.

40 A. Kowalski, LPR, PR i UPR razem, «ND» 11 IX 2007, № 212, p. 3.

41 Dziesięć najważniejszych punktów programowych KW LPR, «SL» № IV.2007/03. 
$2,1 \%$ and no $6-1,91 \%$. LPR got the fewest votes in districts no 40 (Koszalin) -2560 and no 2 (Wałbrzych) - 2827, and by percentage in districts no 5 (Toruń) $-0,88 \%$, as well as 31 (Katowice) and 38 (Piła) $-0,97 \% 42$. In result of the defeat Giertych resigned from the post of the Head of the Executive Board, and Sylwester Chruszcz was nominated in his place ${ }^{43}$.

The period after 2007 was marked by downfall of LPR significance on the Polish political stage, which was connected with leaving its structures by other activists. In June 2008 Chruszcz and the Head of the Political Council Dobrosz announced the willingness to form a new structure of national, catholic, conservative and people's character, which ended up in an internal conflict and their resignation from their posts, and then leaving the party together with their followers ${ }^{44}$. Elections to the European Parliament forced the leaders of the League to attempt uniting the groups advocating similar values. An opportunity for that was formation, in February 2009, of the Polish branch of the Libertas party, led by an Irishman Declan Ganley. Libertas, which had branches in all EU countries, referred negatively to Union federalization and limiting sovereignty of the member states. LPR was one of the founders of Libertas Poland and Daniel Pawłowiec became one of the Deputy Heads ${ }^{45}$. The lists of Libertas, apart from the politicians of the League, included members of, among others, Poland Forward ('Naprzód Polsko', the party of Dobrosz), Polish People's Party 'Piast', Christian National Union and the Party of Regions, as well as some of the former activists of $\mathrm{LPR}^{46}$. The elections of 07.06.2019 were a failure of the new organization. It received 83754 votes, which comprised $1,14 \%$ of votes nationwide and was insufficient to gain mandates. Most people voted for Libertas in the electoral districts no 8 (Lublin) - 12207 and 10 (Karków) - 9005, and by percentage - in district $8-3,22 \%$ and 5 (Warsaw II) $-2,17 \%$. The lowest support for Libertas was in district 2 (Bydgoszcz) - 3277 votes and no 1 (Gdańsk) - 3676 votes, and by percentage in districts no 11 (Katowice) $-0,63 \%$ and no 4 (Warsaw I) $-0,73 \%{ }^{47}$.

42 Wybory parlamentarne 2007, http://wybory2007.pkw.gov.pl/, (access: 1.10.2018).

43 K. Losz, Z Sejmu do adwokatury, «ND» 25 X 2007, № 250, p. 2.

44 Nowe otwarcie na prawicy: Liderzy LPR tworza szeroka platforme narodowa, katolicka, konserwatywna $i$ ludowa, http://chruszcz.blog.onet.pl/2008/06/27/nowe-otwarcie-naprawicy-liderzy-lpr-tworza-szeroka-platforme-narodowa-katolicka-konserwatywna-iludowa/, (access: 1.10.2018).

45 A. Wiejak, Ganley werbuje do Libertasu, «ND» 2 II 2009, № 27, p. 2; JAC, Libertas Polska, «ND» 21-22 III 2009, № 68, p. 5.

46 Kandydaci LPR z Libertasu, «SL» № VI.2009/03.

47 Wybory do Parlamentu Europejskiego 2009, http://pe2009.pkw.gov.pl/PUE/PL/WYN/M/ index.htm, (access: 1.10.2018). 
After 2009 participation of LPR in elections was more and more limited. The party provided electoral lists only during municipal elections in 2010 and 2014, in which it failed. During the first election the League registered lists in 11 voivodeships (all without Lower Silesia, Lubusz, Opole, Podlasie and Warmian-Masurian). During elections of 21.09.2010 it received 87545 votes, which on the scale of 11 voivodeships comprised $0,75 \%$ of all validly casted votes and did not enable the party to receive any mandate ${ }^{48}$. Four years later, however, LPR managed to register lists of candidates to municipal governments in 4 voivodeships - Lubusz, Lesser Poland, Pomeranian and Silesia. On 16.11.2014 34054 people voted for the party, which on the scale of those voivodeships comprised $0,89 \%$ of all validly casted votes. The party, similarly like in 2010 , did not gain any mandate ${ }^{49}$. The parliamentary elections of 2011 and 2015, as well as the EU elections in 2014 were not participated by the League. The leaders of the party decided that it did not have chances to achieve success in the elections and they withdrew from participation ${ }^{50}$.

\section{RÉSUMÉ}

The article comprises an analysis of political relevance of the League of Polish Families (LPR) - the only party of the national movement in the Republic of Poland that introduced its representatives to the parliament and was a member of government coalition. Thanks to its presence in legislative and executive institutions it was able to participate directly in the legislative processes, implement its ideological concepts and control the government with regard to its functioning. LPR was a party that had significant potential to become an important political entity of national character. The union of national and national-conservative groups, as well as the program directed to a large part of the society sharing similar values provided the party with electoral success in the first years of its existence. This resulted from the belief of the national electorate that LPR had become an effective representative of their interests in the public sphere- the interests so far not pursued by Polish authorities. LPR was not able to make use of those assets; its failure

48 Wybory samorzadowe 2010, http://wybory2010.pkw.gov.pl/geo/pl/000000.html, (access: 1.10.2018).

49 Wybory samorzadowe 2014, https://samorzad2014.pkw.gov.pl/, (access: 1.10.2018).

50 Ważna decyzja wyborcza Zarządu Głównego LPR, http://www.lpr.pl/pl/2011/08/16/waznadecyzja-wyborcza-zarzadu-glownego-lpr/, 1.10.2018; Stanowisko Rady Politycznej Ligi Polskich Rodzin w sprawie wyborów do Sejmu i Senatu, http://www.lpr.pl/pl/2015/10/09/ stanowisko-rady-politycznej-ligi-polskich-rodzin-w-sprawie-wyborow-do-sejmu-i-senatu/, 1.10.2018; Stanowisko LPR w sprawie wyborów do Parlamentu Europejskiego, http://www. lpr.pl/pl/2014/05/21/stanowisko-lpr-w-sprawie-wyborow-do-parlamentu-europejskiego/, (access: 1.10.2018). 
resulted from ideological and personal disputes between the activists, which contributed to breakdowns, division of the electorate and gradual decrease of influence of the party in the society.

\section{Bibliography}
A. Antoszewski, Relewancja partii politycznej, [in:] A. Antoszewski, R. Herbut (eds.), Encyklopedia politologii, vol. 3: Partie i systemy partyjne, Kraków 1999.
C. Maj, E. Maj, Narodowe ugrupowania polityczne w Polsce: 1989-2001, Lublin 2007. 